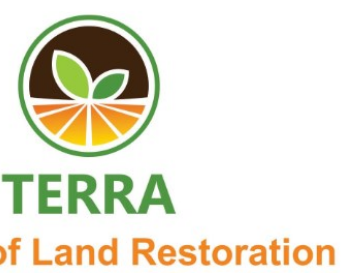

\title{
Vermicompost of Cow Dung and Goat Manure to Increase N Absorption, Mustard (Brassica rapa L) Growth and Yield in Ultisols
}

\author{
Tulus Roy Rasdian Purba ${ }^{1}$, R. Teguh Adi Prasetyo ${ }^{1}$, Bambang Gonggo Murcitro ${ }^{1 *}$ \\ Abimanyu Dipo Nusantara ${ }^{1}$, Eko Suprijono ${ }^{2}$ \\ ${ }^{1}$ Soil Science Department University of Bengkulu, Bengkulu, 38121, Indonesia \\ ${ }^{2}$ Agroecotechnology Department, University of Bengkulu, Bengkulu, 38121, Indonesia \\ email :bgonggo@unib.ac.id
}

\begin{abstract}
This study aims to obtain $N$ levels and $N$ absorption as well as the growth and yield of mustard plants in ultisol soilapplied vermicompost cattle or goats. This research has been conducted from April 2020 - May 2020. Implementation of research on UNIB garden and Soil Science Laboratory of Faculty of Agriculture, University of Bengkulu. This study used a Complete Randomized Design (CRD) with a single factor consisting of 7 treatments, namely control, vermicompost cow dung with a dose of 10 tons $\mathrm{ha}^{-1}, 20$ tons $\mathrm{ha}^{-1}$, and 30 tons ha $\mathrm{a}^{-1}$, and vermicompost goat manure with a dose of 10 tons $\mathrm{ha}^{-1}, 20$ tons $\mathrm{ha}^{-1}$, and 30 tons $\mathrm{ha}^{-1}$. The results showed that the administration of vermicompost cow dung at a dose of 30 tons $\mathrm{ha}^{-1}$ gave the best results for $N$ tissue levels, $N$ absorption, and mustard results in Ultisol. The same result was obtained from the administration of vermicompost goat manure at a dose of 20 tons $\mathrm{ha}^{-1}$.
\end{abstract}

Keywords : Ultisol, vermicompost, nitrogen, cow dung, goat manure

\section{INTRODUCTION}

Ultisol is one type of land spread in Indonesia, with a distribution of $45,794,000$ ha or equal to $25 \%$ of the land area of Indonesia (Subagyo et al., 2004). Ultisol generally has alkaline saturation $<35 \%$, sour to very sour reaction ( $\mathrm{pH} 5-3.1$ ), good drainage, smooth to medium texture, low soil nutrient content, and clay CEC $<12$ me $100 \mathrm{~g}^{-1}$ clay (Hermawan et al., 2014). Ultisol in Bengkulu Province has a cross-section of land in a flat to mountainous form, slopes of $1-40 \%$, with an area of 706,000 ha which is the second widest type of land after inceptisol. From this description, it can be concluded that ultisol fertility potential is low to very low.

Soil fertility quality can be improved by adding organic matter. Organic materials can improve the properties of Ultisol and also able to increase crop yields. The addition of organic matter to the soil has a very important function in fertilizing the topsoil layer, increasing the population of microorganisms in the soil, increasing the absorption of water by the soil, and overall improving the quality of soil fertility and there are important supporting factors in organic farming is organic fertilizer.

Vermicompost is an organic fertilizer obtained through a process involving earthworms in the process of decomposition or decomposition of organic matter. Although most of the decomposition is done by the bodies, the presence of worms helps facilitate the decomposition process. Because the material that will be decomposed by the decomposing bodies has been decomposed first by worms. The composting process involving earthworms is known as vermicompost (Agromedia, 2007 ; Nusantara et al., 2010).

Mustard (Brassica rapa L.) is a leaf vegetable that requires a lot of nitrogen in vegetative growth. This condition will also be encouraged if it contains a lot of organic matter and enough moisture (Yulia et al., 2011). Mustard also grows both in the lowlands and highlands, so it is suitable for cultivation in Indonesia (Haryanto et al., 2006). The addition of organic matter to mustard planting has the potential to replace the use of synthetic chemical fertilizers (Agustina et al., 2012)

One of the sources of $\mathrm{N}$ that is widely used is Urea with a content of $45 \% \mathrm{~N}$, so it is good for the growth process of mustard plants, especially plant 
harvested leaves. Also, Urea fertilizer has hygroscopic properties easily soluble in water and reacts quickly so that, quickly also absorbed by the roots of plants. The dose of Urea applied to plants will determine the growth of mustard plants (Lingga \& Marsono, 2007).

The purpose of this study is to obtain N levels and $\mathrm{N}$ absorption, as well as the growth and yield of mustard plants on ultisol soil, applied vermicompost cattle or goats .

\section{MATERIALS AND METHODS}

This research has been conducted from April 2020 - May 2020. The implementation of research in the garden of UNIB and Soil Science Laboratory of the Faculty of Agriculture, University of Bengkulu.

This study used a Complete Randomized Design (CRD) with a single factor consisting of 7 treatments and 3 tests, resulting in 21 experimental units. Each experimental unit consists of 3 plants so that there are a total of 63 polybags. The treatment tested successive control equivalent to 0 ton $\mathrm{ha}^{-1}\left(\mathrm{~V}_{\mathrm{o}}\right)$, vermicompost cow 10 ton $\mathrm{ha}^{-1}$ equivalent to $25 \mathrm{~g}$ poly$\operatorname{bag}^{-1}\left(\mathrm{~V}_{1}\right)$, Vermicompost cow 20 ton ha ${ }^{-1}$ equivalent to $50 \mathrm{~g}$ polybag $^{-1}\left(\mathrm{~V}_{2}\right)$, Vermicompost cow 30 ton ha ${ }^{1}$ equivalent to $75 \mathrm{~g}$ polybag $^{-1}\left(\mathrm{~V}_{3}\right)$, Vermicompost kambing 10 ton ha ${ }^{-1}$ equivalent to $25 \mathrm{~g} \mathrm{polybag}^{-1}$ $\left(\mathrm{V}_{4}\right)$, Vermicompost kambing 20 ton $\mathrm{ha}^{-\mathrm{P}}$ equivalent to 50 g polybag-1 $\left(\mathrm{V}_{5}\right)$, and Vermicompost goat 30 ton ha ${ }^{-1}$ equivalent to $75 \mathrm{~g} \mathrm{polybag}^{-1}\left(\mathrm{~V}_{6}\right)$.

The stage of implementation of this research began from the manufacture of vermicompost with worm growing media consisting of animal feces and sifted soil with a sieve of $2 \mathrm{~mm}$ with a ratio of $1: 3$. Animal manure used is cow dung and goat manure mixed to homogeneous with soil and placed in a plastic bucket container with a diameter of $45 \mathrm{~cm}$, the lower diameter of $32 \mathrm{~cm}$, and height of $16 \mathrm{~cm}$.

Further preparation of the soil is carried out. Soil samples were taken compositely with a hoe in the ground at $20 \mathrm{~cm}$. furthermore the soil that has been taken is then wind-cooled and sifted with a 2 $\mathrm{mm}$ sieve. Then the soil is taken $1 \mathrm{~kg}$ to be analyzed in the laboratory. Initial soil samples were analyzed to determine nutrient characteristics including $\mathrm{N}$ total, P-available, $\mathrm{K}$-dd, $\mathrm{pH}, \mathrm{C}$-organic, $\mathrm{CEC}$, and moisture content.

After that seed seedlings can be done by using topsoil soil. Before sown the seeds are soaked with water for one night. Then the mustard seed is inserted into a small size polybag, then covered with soil $1-2 \mathrm{~cm}$ thick, and water with a sprayer.

The preparation of mustard seeds is done two weeks before planting in the planting media. Mustard seedlings are selected with the same size height then planted 1 grain/polybag size $5 \mathrm{~kg}$, after planting given basic fertilizer Urea, SP36, and $\mathrm{KCl}$, and given half a dose or $50 \%$ recommendation of mustard plants so that each to $50 \mathrm{~kg} \mathrm{ha}^{-1}$ Urea, $50 \mathrm{~kg} \mathrm{ha}^{-1}$ SP36, and $37.5 \mathrm{~kg} \mathrm{ha}^{-1} \mathrm{KCl}$.

Maintenance of mustard plants includes watering with water that is done every day in the morning and evening. Embroidery is done to replace dead seedlings 3-7 days after planting. Harvesting is done after mustard at the age of 32 dap. Observation Variable consists of the main variable consisting of absorption, plant height $(\mathrm{cm})$, number of leaves (strands), leaf width $(\mathrm{cm})$, the weight of upper fresh biomass weight $(\mathrm{g})$, dry root weight $(\mathrm{g})$, fresh root weight (g) and supporting variables consisting of initial soil analysis, vermicompost analysis, and precipitation $(\mathrm{mm})$.

The observation data were analyzed by variance using $\mathrm{F}$ test at $5 \%$ level. The average difference between treatments tested with DMRT was $5 \%$.

\section{RESULTS AND DISCUSSION}

\section{Mustard Plant Growth}

Observation of mustard plant growth starts from the age of 1 wap to 5 wap presented in Figures 1,2 , and 3 . The results showed that the height of the plant increased sharply at the age of 2 wap and 3 wap, but after that, the height of the plant tended not to increase. The application of 30 tons $\mathrm{ha}^{-1}$ of vermicompost from goat manure resulted in higher plant height compared to other treatments at all observation times (Figure 1).

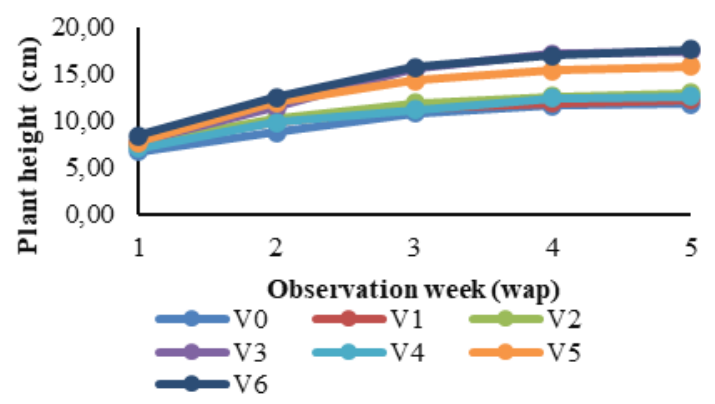

Figure 1. Graph of plant height due to vermicompost application at each observation week

Leaf width continued to experience a sharp increase until 4 wap observations, but at 5 wap the leaf width did not tend to experience a sharp increase. When the plants were 1 wap and 2 wap, giving 20 tons of ha-1 vermicompost from goat manure tended to be wider than the other treatments. However, when the plants were 3 wap, 4 wap, and 5 wap, the application of 30 ton ha-1 vermicompost 
from cow dung tended to be wider than the other treatments (Figure 2)

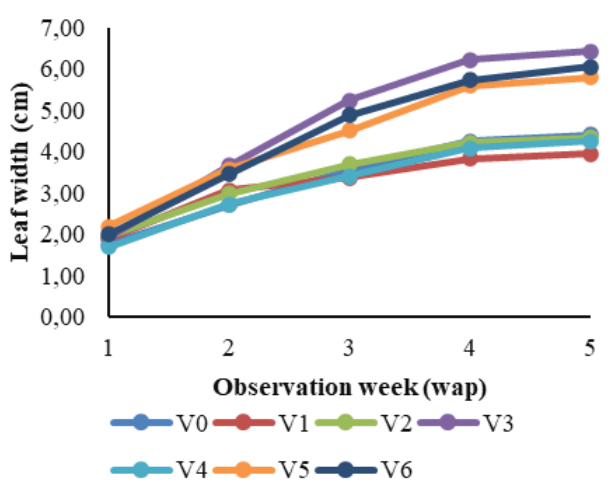

Figure 2. Graph of leaf width due to vermicompost application at each observation week

The number of leaves continued to experience a sharp increase until 4 wap observations, but at the age of 5 the number of leaves did not tend to experience a sharp increase. When the plants were 1 wap and 2 wap, giving 20 tons of ha- 1 vermicompost from goat manure tended to produce more leaves compared to other treatments. However, when the plants were 3 wap, 4 wap, and 5 wap, the provision of 30 tons ha- 1 of vermicompost from goat dung tended to be more numerous than the other treatments (Figure 3).

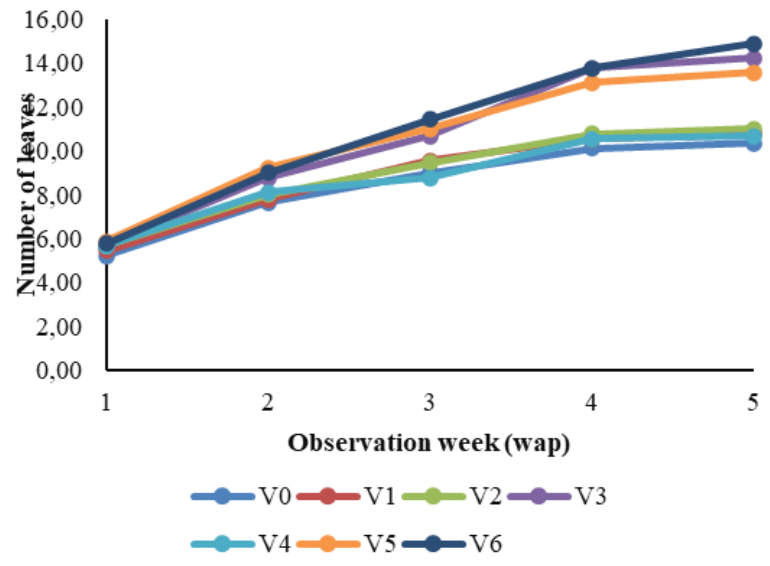

Figure 3. Graph of the number of leaves due to the application of vermicompost at each observation week

In general, the results showed that mustard growth covering plant height, leaf width, and leaf count showed an increase in each observation. The increase in mustard growth which includes the height of the plant, the width of the leaves, and the number of leaves indicates the pattern tends to be the same on each observation. The rate of growth of a plant changes by time. Therefore, if the rate of growth ordinate and the time of abscess, then the graph is a curve in the form of a sigmoid curve .

\section{Analysis of Variance Results}

The results of the variant analysis showed that the administration of vermicompost had a noticeable influence on $\mathrm{N}$ tissue levels, $\mathrm{N}$ absorption, plant height, leaf width, number of leaves, fresh weight, and dry upper plant, but had no noticeable effect on the fresh and dry weight of the roots (Table 1).

Table 1. Results of variance analysis of observed variables

\begin{tabular}{l|c|c|c|}
\hline Variable & F-calc & F-table 5\% & CV (\%) \\
\hline N levels of plant tissue & $9.44^{*}$ & 2.85 & 5.07 \\
\hline N uptake & $6.58^{*}$ & 2.85 & 15.46 \\
\hline Plant height & $8.52^{*}$ & 2.85 & 10.39 \\
\hline Leaf width & $6.62^{*}$ & 2.85 & 13.61 \\
\hline Number of leaves & $8.00^{*}$ & 2.85 & 9.7 \\
\hline $\begin{array}{l}\text { Upper fresh biomass } \\
\text { weight }\end{array}$ & $7.23 *$ & 2.85 & 15.68 \\
\hline Fresh root weight & 0.59 ns & 2.85 & 23.81 \\
\hline Upper biomass dry weight & $7.72 *$ & 2.85 & 10.93 \\
\hline Dry root weight & $0.66 \mathrm{~ns}$ & 2.85 & 20.77 \\
\hline ns= does not differ significantly. $*$ different significantly at the F-table level at $5 \%$ \\
\hline
\end{tabular}

$N$ levels of plant tissue and $N$ uptake

The results showed that vermicompost produced $\mathrm{N}$ levels of plant tissue and $\mathrm{N}$ uptake that were significantly different. $\mathrm{N}$ levels of plant tissue is the highest in the treatment of vermicompost from cow dung with a dose of 30 tons $\mathrm{ha}^{-1}$ which is $2.75 \%$. While the lowest $\mathrm{N}$ levels of plant tissue produced by vermicompost application with a dose of 10 tons ha ${ }^{-1}$ is $2.17 \%$, although it differs not significantly from other treatments except by the administration of vermicompost from cow manure at a dose of 30 tons ha ${ }^{-1}$ (Table 2). The results showed that the treatment of vermicompost from cow dung with a dose of 30 tons $\mathrm{ha}^{-1}$ is the right one in increasing the availability of $\mathrm{N}$ in the soil so that its absorption increases. The results of laboratory analysis showed that vermicompost cow dung has an $\mathrm{N}$ level of $1.66 \%$, then $\mathrm{N}$ levels in vermi compost goat manure by $1.90 \%$. The application of organic fertilizer provides the advantage of increasing the availability of essential nutrients in addition to improving soil properties and processes that occur in the soil, so that soil nutrient absorption increases (Purakayastha et al., 2008). Yuka et al. (2017) reported that administration of vermicompost at a dose of $30 \%(1.75 \mathrm{~kg}$ 
$10 \mathrm{~kg}_{-}{ }^{1}$ media) increases $\mathrm{N}$ levels of plant tissue in cucumber plants.

Table 2. Effect of vermicompost on $\mathrm{N}$ levels plant tissue and $\mathrm{N}$ uptake

\begin{tabular}{|c|c|c|c|}
\hline \multicolumn{2}{|c|}{ Treatment } & \multirow{2}{*}{$\begin{array}{c}\text { Nlevels } \\
\text { plant } \\
\text { tissue }(\%)\end{array}$} & \multirow{2}{*}{$\begin{array}{l}\text { N uptake } \\
\text { (mg) }\end{array}$} \\
\hline Vermicompost & $\begin{array}{c}\text { Dose (ton } \\
\text { ha-1) }\end{array}$ & & \\
\hline Control & 0 & $2.24 \mathrm{~b}$ & $36.33 \mathrm{~b}$ \\
\hline Cow dung & 10 & $2.22 \mathrm{~b}$ & $37.62 \mathrm{~b}$ \\
\hline Cow dung & 20 & $2.18 \mathrm{~b}$ & $41.09 \mathrm{~b}$ \\
\hline Cow dung & 30 & $2.75 \mathrm{a}$ & $102.46 \mathrm{a}$ \\
\hline Goat manure & 10 & $2.17 \mathrm{~b}$ & $38.58 \mathrm{~b}$ \\
\hline Goat manure & 20 & $2.22 \mathrm{~b}$ & $73.68 \mathrm{ab}$ \\
\hline Goat manure & 30 & $2.21 \mathrm{~b}$ & 91.89 a \\
\hline
\end{tabular}

$\mathrm{N}$ levels plant tissue has a close relationship with $\mathrm{N}$ uptake mustard plant, the higher $\mathrm{N}$ levels plant tissue than the greater $\mathrm{N}$ uptake plant. This is evident from the results of research that shows that in addition to producing the highest $\mathrm{N}$ levels of plant tissue, the administration of vermicompost from cow dung at a dose of 30 tons $\mathrm{ha}^{-1}$ also produced the highest $\mathrm{N}$ uptake of $102.46 \mathrm{mg}$ although equally good as the application of vermicompost from goat manure at doses of 20 tons $\mathrm{ha}^{-1}$ and 30 tons of ha ${ }^{-1}$ (Table 2). In line with the results of research Kurniawati et al. (2017) showed that the high level of plant tissue $\mathrm{N}$ has an impact on the high $\mathrm{N}$ uptake in mustard plants. The uptake of $\mathrm{N}, \mathrm{P}$ and $\mathrm{K}$ in plant tissues is strongly influenced by the application of vermicompost. Plant nutrient uptake highly depends on the nutrient release from the soil solid phase in the form of mineral and organic materials to the soil solution. The release of nutrients from organic matter occurs biochemically through the balance of mineralization and immobilization processes, while from mineral materials occurs physicochemically through adsorption and desorption, and precipitation and dissolution (Nurhidayati et al., 2018).

\section{Growth and yield of mustard plants}

The results showed that the treatment of vermicompost from goat manure at a dose of 30 tons $\mathrm{ha}^{-1}$ produced the highest plant height of $17.61 \mathrm{~cm}$ and the most number of leaves was 14.89 strands, while the widest leaf produced vermicompost from cow dung at a dose of 30 tons $\mathrm{ha}^{-1}$ which is $6.42 \mathrm{~cm}$. Nevertheless, the administration of vermicompost from goat manure at a dose of 30 tons ha-1, as well as from the application of vermicompost of goat manure at doses of 20 tons ha ${ }^{-1}$ and 30 tons of ha ${ }^{-1}$ produce plant height, leaf width, and some leaves equally well (Table 3). This is due to the administration of vermicompost from goat manure at a dose of 30 tons $\mathrm{ha}^{-1}$, as well as from the application of vermicompost of goat manure at doses of 20 tons $\mathrm{ha}^{-1}$ and 30 tons of ha ${ }^{-1}$ supplying nutrients especially $\mathrm{N}$ for higher plants compared to other treatments indicated by $\mathrm{N}$ levels plant tissue and $\mathrm{N}$ uptake better (Table 2). Higher of $\mathrm{N}$ uptake has an impact on improving the growth of mustard plants. Nitrogen is the main nutrient for plant growth, which is generally indispensable for the formation and growth of vegetative parts of plants such as leaves, stems, and roots (Sutedjo, 2002). Nitrogen is an important part of the formation of chlorophyll, protoplasm, proteins, and nucleic acids. This element has an important role in the growth and development of all living networks (Brady \& Weil, 2002). Sarif et al. (2015) report that the addition of nitrogen to plants can encourage the growth of photosynthetic-related organs such as leaves. In addition, the effects of vermicompost on plants are not only due to the quality of mineral nutrients available but also to other growths such as regulating plant growth hormone and humic acid (Norman et al., 2005). Organic fertilizer using a vermicompost system can increase plant growth (Talkah, 2010). Vermicompost can minimize the quantity of inorganic fertilizers, recycle the farm waste, and increase the physical properties of soil (Kansotia et al., 2015)..

Table 3. Effect of vermicompost on plant height, leaf width and number of leaves

\begin{tabular}{|c|c|c|c|c|}
\hline \multicolumn{2}{|c|}{ Treatment } & \multirow{2}{*}{$\begin{array}{l}\text { Plant height } \\
\quad(\mathrm{cm})\end{array}$} & \multirow{2}{*}{$\begin{array}{l}\text { Leaf width } \\
\quad(\mathrm{cm})\end{array}$} & \multirow{2}{*}{$\begin{array}{l}\text { Number of } \\
\text { leaves }\end{array}$} \\
\hline Vermicompost & $\begin{array}{c}\text { Dose (ton } \\
\text { ha-1) }\end{array}$ & & & \\
\hline Control & 0 & $11.84 \mathrm{~b}$ & $4.40 \mathrm{~b}$ & $10.33 \mathrm{~b}$ \\
\hline Cow dung & 10 & $12.26 \mathrm{~b}$ & $3.94 \mathrm{~b}$ & $10.78 \mathrm{~b}$ \\
\hline Cow dung & 20 & $12.97 \mathrm{~b}$ & $4.33 \mathrm{~b}$ & $11.00 \mathrm{~b}$ \\
\hline Cow dung & 30 & $17.49 \mathrm{a}$ & $6.42 \mathrm{a}$ & $14.22 \mathrm{a}$ \\
\hline Goat manure & 10 & $12.66 \mathrm{~b}$ & $4.26 \mathrm{~b}$ & $10.67 \mathrm{~b}$ \\
\hline Goat manure & 20 & $15.80 \mathrm{a}$ & $5.79 \mathrm{a}$ & $13.56 \mathrm{a}$ \\
\hline Goat manure & 30 & $17.61 \mathrm{a}$ & $6.04 \mathrm{a}$ & $14.89 \mathrm{a}$ \\
\hline \multicolumn{5}{|c|}{$\begin{array}{l}\text { The number of each colomn followed with the same character were } \\
\text { not significantly different }(\mathrm{P}>0.05)\end{array}$} \\
\hline
\end{tabular}


The results showed that the application of vermicompost from cow dung at a dose of 30 tons ha ${ }^{-1}$ produced the heaviest fresh biomass fresh weight upper of $39 \mathrm{~g}$, while the heaviest dry weight upper biomass was produced by vermicompost of goat manure on the dose of 30 tons ha ${ }^{-1}$ which is $3.60 \mathrm{~g}$. Vermicompost application of cow dung and goat manure at doses of 20 tons $\mathrm{ha}^{-1}$ and 30 tons of ha produces an equally good and heavier upper fresh biomass weight and upper biomass dry weight compared to other treatments (Table 4). This is because vermicompost used contains $\mathrm{N}$ elements so that it's feeding into the soil directly increases the availability of $\mathrm{N}$ for plants and the absorption of $\mathrm{N}$ also increases. According to Wijaya (2008) that the application of nitrogen in plants will encourage the growth of organs related to photosynthesis, namely leaves. Plants that get enough nitrogen supply will form leaves that have a wider leaf with higher chlorophyll content so that plants can produce carbohydrates in sufficient quantities to support their vegetative growth.

Vermicompost has many advantages when compared to other organic fertilizers because vermicompost is rich in macro and micro essential nutrients and contains plant growth hormones such as auxin, gibberelin, and cytokines that are needed for maximum plant growth (Marsono \& Sigit, 2001). The same results were shown by Bosekeng's research (2019) that the increase in vermicompost dose in the range of $50 \%$ and $100 \%$ was followed by an increase in the number of leaves, the height of the plant, length of leaves, leaf width, leaf area, and leaf weight. The increased leaf change due to the application of vermicompost makes the process of photosynthesis take place better.

Table 4. Effect of vermicompost on fresh and dry biomassa weight

\begin{tabular}{|c|c|c|c|c|c|}
\hline \multicolumn{2}{|c|}{ Treatmen } & Fresh biomass weight (g) & Dry biomass weight (g) \\
\hline Vermicompost & $\begin{array}{c}\text { Dose (ton } \\
\text { ha-1) }\end{array}$ & Upper & Root & Upper & Root \\
\hline Control & 0 & $15.33 \mathrm{bc}$ & 0.44 & $1.29 \mathrm{~b}$ & 0.35 \\
\hline Cow dung & 10 & $11.67 \mathrm{c}$ & 0.72 & $1.00 \mathrm{~b}$ & 0.69 \\
\hline Cow dung & 20 & $15.03 \mathrm{bc}$ & 0.51 & $1.38 \mathrm{~b}$ & 0.52 \\
\hline Cow dung & 30 & $39.00 \mathrm{a}$ & 0.81 & $3.28 \mathrm{a}$ & 0.49 \\
\hline Goat manure & 10 & $13.78 \mathrm{c}$ & 0.63 & $1.26 \mathrm{~b}$ & 0.51 \\
\hline Goat manure & 20 & $29.67 \mathrm{ab}$ & 0.73 & $2.79 \mathrm{a}$ & 0.53 \\
\hline Goat manure & 30 & $36.67 \mathrm{a}$ & 0.76 & $3.60 \mathrm{a}$ & 0.55 \\
\hline
\end{tabular}

The provision of organic materials in the form of vermicompost is also able to increase the availability of water in the soil so that plants are sufficient for their water needs which leads to increased fresh biomass plants. This is following the results of research Lawenga et al. (2015) that organic matter can improve the physical properties of soil, especially on soil content weight, porosity, and permeability. According to Habi (2015) that organic matter can spur the formation of soil aggregates indicated by a decrease in soil bulk density and increased soil pore space. Therefore, it is natural that the provision of organic fertilizer in the form of cow dung is proven to increase plant growth (Ramadhani et al., 2019).

\section{CONCLUSION}

Based on the evaluation of the results and discussion above can be concluded that the administration of vermicompost cow dung at a dose of 30 tons $\mathrm{ha}^{-1}$ provides the best results for $\mathrm{N}$ tissue levels, $\mathrm{N}$ absorption, and mustard results in Ultisol. The same result was obtained from the administration of vermicompost goat manure at a dose of 20 tons $\mathrm{ha}^{-1}$.

\section{References}

Agromedia, R. (2007). Petunjuk Pemupukan. Agromedia, Jakarta.

Agustina L, Intan .P.W., Koestiharti \& Khumairoh, U. (2012). Intercropping sweet corn (Zea mays saccharata Sturt) and pakchoy (Brassica juncea) in the different organic matter compositions. J. Agric. Food. Tech., 2(2) 35-40.

Bosekeng, G. (2019). Response of Ethiopian mustard (Brassica carinata A. Braun) to different levels of vermicompost in North East, Botswana. World Journal of Agricultural Research, 7(3), 112-118. DOI : https://10.12691/wjar-7-3-5.

Brady, N.C.\& Weil, R.R. (2002(. The Nature and Propertiesof Soils. 13'* Edition. Upper Saddle River. New Jersey, USA.

Habi, M.L. 2015. Pengaruh aplikasi kompos granulela sagu diperkaya pupuk Ponska terhadap sifat fisik tanah dan hasil jagung manis di Inceptisol. Biopendix, 1(2), 121-134.

Haryanto, B., Suhartini, T., Rahayu, E. \& Sunarjo. (2006). Sawi dan Selada. Penebar Swadaya, Jakarta.

Hermawan, A., Sabarudin, Marsi, Hayati, R. \& Warsito. (2014). Perubahan jerapan P pada Ultisol akibat pemberian campuran abu terbang batubara kotoran ayam. Jurnal Ilmu Tanah dan Agroklimatologi, 11(1), 1-10.

Kansotia, B.C., Sharma, Y. \& Meena, R.S. (2015). Effect of vermicompost and inorganic fertilizers on soil properties and yield of Indian mustard (Brassica juncea L.). Journal of Oilseed Brassica, 6 (1), 198-201. 
Kurniawati, A., Melati, M., Aziz, S.A. \& Purwono. (2017). Pengurangan dosis pupuk pada produksi sawi hijau organik dengan pergiliran tanaman jagung dan Kedelai. J. Agron. Indonesia, 45 (2), 188-195.

Lawenga, F.F., Hasanah, U. \& Widjajanto, D. (2015). Pengaruh pemberian pupuk organik terhadap sifat fisika tanah dan hasil tanaman tomat (Lycopersicum esculentum Mill.) di Desa Bulupountu Kecamatan Sigi Biromaru Kabupaten Sigi. $e$ J. Agrotekbis, 3(5), 564-570.

Lingga, P. \& Marsono. (2007). Petunjuk Penggunaan Pupuk. Edisi Revisi Penebar Swadaya, Jakarta.

Norman, Arancon, Q. \& Edwards, C.A. (2005). Effects of Vermicomposts on Plant Growth. Paper Presented during the International Symposium Workshop on Vermi Technologies for Developing Countries. The Ohio State University, Columbus, USA.

Nurhidayati, N., Machfudz, M. \& Murwani, I. (2018). Direct and residual efect of various vermicompost on soil nutrient and nutrient uptake dynamics and productivity of four mustard Pak-Coi (Brassica rapa L.) sequences in organic farming system. International Journal of Recycling of Organic Waste in Agriculture, 7, 173-181. DOI: https://doi.org/10.1007/s40093-018-0203-0.

Nusantara, A.D., Kusmana, C., Mansur, I., Darusman, L.K. \& Soedarmadi. (2010). Pemanfaatan vermikompos untuk produksi biomassa legum penutup tanah dan inokulum fungi mikoriza arbuskula.Jurnal Ilmu-Ilmu Pertanian Indonesia, 12(1), 26-33. DOI: https://doi.org/ 10.31186/ jipi.12.1.26-33.
Purakayastha, T.J., Rudrappa, L., Singh, D., Swarup, A. \& Bhadraray, S. (2008). Long-term impact of fertilizers on soil organic carbon pools and sequestration rates in Maize-Wheat-Cowpea Cropping System. Geoderma, 144(2), 370-378.

Ramadhani, C., Sumardi \& Murcitro, B.G. (2019). Pemberian dua jenis ameliorant terhadap performa tanaman Okra (Abelmoschus esculentus) pada Ultisol. Jurnal Ilmu-Ilmu Pertanian Indonesia, 21(2),121-128.DOI: https://doi.org/ 10.31186/ jipi.21.2.121-128.

Sarif, P., Hadid, A. \& Wahyudi, I. (2015). Pertumbuhan dan hasil tanaman sawi (Brassica juncea L.) akibat pemberian berbagai dosis pupuk urea. e-J. Agrotekbis, 3(5), 585-591.

Subagyo, Suharta, H.N. \& Siswanto, A.B. (2004). Tanahtanah pertanian di Indonesia. Pp. 21-66. In A. Adimihardja, L.I. Amien, F. Agus, dan D. Djaenudin (Ed.). Sumberdaya Lahan Indonesia dan Pengelolaannya. Pusat Penelitian dan Pengembangan Tanah dan Agroklimat, Bogor

Talkah, A. (2010). Kajian Pengolahan Limbah Jengkok Tembakau Industri Rokok sebagai Pupuk Organik. Disertasi. Program Doktor Ilmu Pertanian. Fakultas Pertanian. Universitas Brawijaya, Malang.

Yuka, M. F., Niswati, A. \& Hendarto, K. (2017). Pengaruh dosis vermikompos terhadap pertumbuhan produksi dan serapan N \& P tanaman mentimun (Cucumis sativus L.) pada dua kedalaman tanah Ultisol.Jurnal Penelitian Pertanian Terapan, 17(2), 117-123.

Yulia, A., Murniati \& Fatimah. (2011). Aplikasi pupuk organik pada tanaman caisim untuk dua kali penanaman. Sagu, 10(1), 14-19. 